Przegląd Prawa Konstytucyjnego

----ISSN 2082-1212-----

DOI 10.15804/ppk.2018.03.08

-----Nr $3(43) / 2018-----$

\title{
Sprawozdanie
}

\section{Wykład Profesor Ewy Lętowskiej Zmierzch liberalnego państwa prawa w Polsce? \\ Uwagi o kryzysie konstytucyjnym w Polsce 2015-2018, Wydzial Matematyczno-Fizyczny Uniwersytetu Szczecińskiego, Szczecin 5 kwietnia $2018 \mathrm{r}$.}

Dnia 5 kwietnia 2018 r. na Wydziale Matematyczno-Fizycznym Uniwersytetu Szczecińskiego odbył się, połączony z dyskusją, wykład prof. Ewy Łętowskiej, poświęcony zagadnieniom kryzysu konstytucyjnego w Polsce w latach 20152018. W spotkaniu udział wzięli przedstawiciele szczecińskich środowisk naukowych, zawodów prawniczych oraz licznie zgromadzeni studenci. Zebranych powitał JM Rektor Uniwersytetu Szczecińskiego prof. zw. dr hab. Edward Włodarczyk, przedstawiając gościa. Prelegentka wskazała, że czynione rozważania oscylować będą wokół jej doświadczeń, zdobytych przy obserwacji funkcjonujących obecnie mechanizmów działania państwa. Za punkt wyjściowy rozważań przyjęto paradygmat Konstytucji Rzeczypospolitej Polskiej z 2 kwietnia 1997 r. ${ }^{1}$

Aktualna sytuacja wskazuje bezsprzecznie, że doszło do zmiany „kierunku marszu”, choć pierwotnie zmiana była mało widoczna. O ile niegdyś zmierzaliśmy ku klasycznemu, liberalnemu państwu prawa, o tyle obecnie zmierzamy ku autorytarianizmowi, tj. systemowi, który w praktyce kwestionuje deliberatywny sposób uzyskiwania zgody na decyzje w państwie, w konsekwencji czego postępuje powolne ograniczenie pola manewru wyborców.

1 Dz.U. Nr 78, poz. 483 ze zm., zwana dalej „Konstytucją RP”. 
Ażeby ustalić, czy tak jest w rzeczywistości, wykazać należy, jak proces tego rodzaju przebiega. Zdaniem prelegentki, składa się on z dwóch etapów. Etap pierwszy to intensywna zmiana prawodawstwa, w szczególności w podstawowych dziedzinach ustroju politycznego, np. prokuratury, mediów publicznych, TK, SN i sądów powszechnych, a także ustroju gospodarczego, np. zasad dysponowania własnością rolną, prawa wodnego, łowiectwa, działalności farmaceutycznej etc. Ten etap trwał około dwóch lat (2015-2017).

Etap drugi to zmiana standardów. Jego istotę dostrzec można jedynie po uprzednim dostrzeżeniu językowego ograniczenia prawników, którzy przywiązani są do formalnej analizy tekstów normatywnych. Ich analizy przedstawiają wynik przeprowadzonej wykładni i dokonanej subsumpcji; nie uwzględniają jednak zmian w prawie zachodzących w czasie. Są zatem jednowymiarowe niczym fotografia, podczas gdy winny być dynamiczne jak film oddawać zmiany. Jest to szczególnie ważne, gdy zmiany są ilościowo ogromne. Nie dostrzega się przeto standardów, a widzi tylko pojedyncze, odseparowane przepisy. Etap drugi zbiera owoce etapu pierwszego. W nim bowiem widać, że nowelizacje ustaw (dokonane w etapie pierwszym) nie doprowadziły do pożądanych zmian. Zmiany te uwidaczniają swoisty „ciąg technologiczny”, na który składają się sekwencja zmian instytucjonalnych w organach państwa, w tym sądach i gwarancjach poszanowania instytucji, zmiany procedur i wymiany kadr. Kadry zmienia się po to, aby zautomatyzować działanie struktur, do czego niezbędna jest ich podatność na sugestie z zewnątrz (kombinacja efektów mrożących i skłaniających). Dokonując zmiany kadr, trzeba baczyć - zdaniem prelegentki - na słowa prof. Zygmunta Ziembińskiego, który wskazał, że niewłaściwe jest nadmierne zaufanie do skutków ex lege. Są one bowiem nieodwracalne, przeto ewentualnych błędów nie sposób naprawić. Zmiany kadr winny odbywać się w ramach rozciągniętego w czasie procesu immanentnie połączonego $\mathrm{z}$ etapowymi zmianami struktur organizacyjnych. Na końcu „ciągu technologicznego” jest zmiana standardu.

Dostrzeżenie etapów dochodzenia do autorytarianizmu doprowadziło prelegentkę do postawienia tezy, że powyższe działania prowadzą do systemowej i wieloaspektowej reglamentacji wolności. Należy mieć tu na uwadze paradygmat Konstytucji RP, zakładający ideę społeczeństwa otwartego, o czym przesądza preambuła włączająca do wspólnoty wszystkich obywateli, 
zarówno wierzących w Boga, będącego źródłem prawdy, sprawiedliwości, dobra i piękna, jak i niepodzielających tej wiary, a te uniwersalne wartości wywodzących z innych źródeł, jak i konsekwentne posługiwanie się pojęciami „każdy” i „obywatel” dla oznaczenia podmiotu wolności, praw i obowiązków, z jednoczesną majoryzacją podmiotowości jednostki, a nie li tylko obywatela. W opozycji do tej idei pozostaje społeczeństwo zamknięte, kładące nacisk na podmiotowość obywateli, posiadających niemalże ekskluzywne wolności, prawa i obowiązki niedostępne nie-obywatelom.

Z aksjologicznego punktu widzenia Konstytucja RP oparta została na wartościach przyświecających Unii Europejskiej ${ }^{2}$. Z ich analizy widać, że nie mamy li tylko szanować litery prawa, lecz musimy szanować pewne, wspólnie wypracowane standardy. Unia Europejska szanuje i uwzględnia pluralizm konstytucyjny swych członków, lecz również przyjmuje wynikającą z tej zasady konsekwencję - paremię patere quam ipse fecisti legem (łac. poddaj się prawu, któreś sam ustanowił). Unia zatem jest legitymowana do żądania realizacji tej zasady, a podejmowane przez nią formalne i nieformalne działania zmierzające do wymuszenia jej realizacji nie mogą zostać uznane za ingerencję uzurpacyjną. Przejawem takich działań są dwie sprawy zawisłe przed Trybunałem Sprawiedliwości UE. W pierwszej, C-64/16³, wskazano, że obniżanie wynagrodzenia sędziów może być (choć w tej konkretnej sprawie tego nie stwierdzono) obniżeniem standardu niezawisłości sędziowskiej. W drugiej zaś, C-216/18 PPU ${ }^{4}$, rozwadze poddane zostanie (rozstrzygnięcie jeszcze nie zapadło), czy niespotykana akumulacja zmian prawodawczych w Polsce

2 Art. 2 Traktatu o Unii Europejskiej (Dz.U. 2004, Nr 90, poz. 864 ze zm.): Unia opiera się na wartościach poszanowania godności osoby ludzkiej, wolności, demokracji, równości, państwa prawa, jak również poszanowania praw człowieka, w tym praw osób należących do mniejszości. Wartości te są wspólne Państwom Członkowskim w społeczeństwie opartym na pluralizmie, niedyskryminacji, tolerancji, sprawiedliwości, solidarności oraz na równości kobiet i mężczyzn.

Wyrok Trybunału Sprawiedliwości UE z 27 lutego 2018 r. w sprawie C-64/16, Associação Sindical dos Juízes Portugueses v. Tribunal de Contas, dostępny w polskiej wersji językowej pod adresem http://curia.europa.eu/juris/document/document.jsf;jsessionid=9ea7d0f130de60c909a4b6f2457bb83bd4f73391f440.e34KaxiLc3eQc40LaxqMbN4Pb38Me0?text=\&docid $=199682$ \&pageIndex $=0 \&$ doclang $=$ PL\&mode $=1$ st $\&$ dir $=\& o c c=$ first $\&$ part $=1 \& \operatorname{cid}=374864$ (02.04.2018).

4 Pytanie prawne sądu irlandzkiego z $2018 \mathrm{r}$. 
nie stanowi obniżenia standardu ochrony prawnej, a w konsekwencji nie uzasadnia odmowy dokonania ekstradycji do Polski.

Konstytucja RP, zdaniem prelegentki, opiera się na czterech filarach: (1) podziale i współpracy władzy, które wymają nie tylko wyodrębnienia funkcji, kompetencji i piastunów, lecz również wzajemnego szacunku władz i wykluczenia wrogości między nimi; (2) subsydiarności centrum, co nie tylko pozwala na podejmowanie decyzji „najbliżej” rzeczywistych potrzeb, lecz również ogranicza zasięg skutków ewentualnych błędów, z których istnieniem należy się pogodzić; (3) szczególnej relacji większości do mniejszości, która nie dąży do dominacji i ubezwłasnowolnienia mniejszości; (4) pojmowaniu suwerena, który niezależnie od przyjętych struktur organizacyjnych musi mieć potencję decyzyjną i nie może być sprowadzany (wobec braku podstaw prawnych) do aktualnej większości parlamentarnej.

Stawiane obecnej władzy zarzuty UE i Komisji Weneckiej co do naruszeń praworządności nie oznaczają zarzutów co do poszczególnych przepisów, lecz odnoszą się do standardów wyprowadzanych z powyższych założeń aksjologicznych. Jest to zatem całkiem inna optyka od postawy władz polskich. Niewystarczające jest zatem do obalenia tych zarzutów wskazanie, że uchwalony przepis X jest tożsamy z przepisem X obowiązującym w innym państwie. Nie dotyczy to analizy standardu, lecz stanowi stricte formalistyczne porównanie przepisów, bez uwzględnienia ich otoczenia normatywnego. Powyższe doprowadziło prelegentkę do konkluzji, zgodnie z którą, jeżeli prawo stanowią tekst aktu normatywnego i standardy (w powyższym rozumieniu), to państwo prawa jest tarczą jednostki przed samowolą władzy.

Po wykładzie nastąpiła dyskusja i odpowiedzi prelegentki na pytania słuchaczy.

Wykład był kolejnym z cyklu spotkań „Odcienie sprawiedliwości”, organizowanego przez samorząd studencki tutejszego Wydziału Prawa i Administracji.

Jan Uniejewski, Anna Pazura Uniwersytet Szczeciński 